\title{
FORMULASI BUAH TAMPOI (Baccaurea macrocarpa) DALAM SEDIAAN MASKER GEL SEBAGAI ANTIAGING
}

\section{Tampoi Fruits Formulation (Baccaurea Macrocarpa) In a Gel Mask Preparation As An Antiaging Agent}

\author{
Ika Avrilina Haryono'** \\ Noval ${ }^{2}$ \\ Bayu Nugraha ${ }^{3}$
}

*ISari Mulia Universiti I, Banjarmasin City, South Borneo 70238, Indonesia

2Sari Mulia Universiti 2, Banjarmasin City, South Borneo 70238, Indonesia

3 Sari Mulia Universiti 3, Banjarmasin City, South Borneo 70238, Indonesia *email: ika.avrilina@yahoo.com

Kata Kunci:

Buah Tampoi

Masker Gel

Antiaging

Keywords:

Tampoi Fruits

Gel Mask

Antiaging

\begin{abstract}
Abstrak
Antioksidan mampu menekan radikal bebas sehingga mengurangi terjadinya reaksi oksidasi, juga efektif untuk mencegah kerusakan kulit akibat proses penuaan. Pemanfaatan ekstrak buah tampoi dalam sediaan masker gel sebagai antioksidan bermanfaat untuk mengatasi permasalahan kulit. Metode yang digunakan eksperimental laboratorium dengan cara membuat sediaan masker gel dari buah tampoi. Pembuatan masker gel dimulai dengan pencampuran basis masker terdiri dari PVA (Polivinil Alkohol), Propylene Glikol, Carborner 940 kemudian ditambah ekstrak buah tampoi. Formulasi masker gel buah tampoi dalam penelitian ini dibuat berdasarkan variasi PVA sebesar FI (3\%), FII (6\%), FIII (I2\%), dan FIV (I8\%) yang bertujuan untuk mengetahui pengaruhnya dan formula paling optimal. Tahapan yang dilakukan meliputi tahap ekstraksi buah tampoi, pembuatan sediaan masker gel dengan 4 formula FI (3\%), F2 (6\%), F3 (I2\%), dan F4 (I8\%) dilanjutkan dengan evaluasi formula yang meliputi uji organoleptis, uji $\mathrm{pH}$, uji vikositas, uji daya sebar dan uji daya lekat. pengujian stabilitas fisik dilakukan selama 4 minggu. Selanjutnya data dianalisis dengan uji statistik ANOVA. Hasil penelitian menunjukkan bahwa terdapat pengaruh yang signifikan terhadap evaluasi uji viskositas dan uji daya lekat pada masing-masing formula. Sedangkan pada uji $\mathrm{pH}$ dan uji daya sebar tidak ada pengaruh yang signifikan pada masing-masing formula. Formula yang optimal berada pada FI dengan konsentrasi PVA 3\%.
\end{abstract}

\begin{abstract}
Antioxidants are able to suppress free radicals, reducing the occurrence of oxidation reactions, and are also effective in preventing skin damage due to the aging process. The use of tampoi fruit extract as a gel mask preparation could have a purpose as an antioxidant to treat skin problems. The method is experimental laboratory by making a gel mask preparation from tampoi fruit. The making of a gel mask begins with mixing the base mask consisting of PVA (Polyvinyl Alcohol), Propylene Glycol, Carborner 940 then added with tampoi fruit extract. The tampoi fruit gel mask formulation in this study was made based on variations in PVA of FI (3\%), FII (6\%), FIII (I2\%), and FIV (I8\%) which aims to determine its effect and the most optimal formula. The steps taken include the extraction of tampoi fruit, making gel masks with 4 formulas FI (3\%), F2 (6\%), F3 (I $2 \%)$, and F4 (I $8 \%$ ) followed by evaluation of formulas which include organoleptic tests, $\mathrm{pH}$ test, viscosity test, spreadability test and adhesion test. Physical stability testing was carried out for 4 weeks. Furthermore, the data were analyzed by using the ANOVA statistical test. The results showed that there was a significant effect on the evaluation of the viscosity test and the adhesion test for each formula. Meanwhile, the $\mathrm{pH}$ test and spreadability test did not have a significant effect on each formula. The optimal formula is in FI with a PVA concentration of $3 \%$.
\end{abstract}

\section{PENDAHULUAN}

Perawatan kulit sangat penting dilakukan untuk mencegah penuaan dini yang biasanya terjadi karena beberapa faktor salah satunya adalah paparan sinar matahari ke kulit. Kulit merupakan bagian luar manusia yang terdiri dari beberapa bagian yaitu epidermis, dermis dan hipodermis. Sepanjang hari kulit bekerja keras untuk melindungi wajah dan bagian luar tubuh. 
Kulit merupakan lapisan pelindung tubuh dari paparan polusi lingkungan, terutama kulit wajah yang sering terpapar oleh sinar ultraviolet (UV) akibatnya dapat menimbulkan masalah kulit seperti keriput, penuaan dini, jerawat dan pori kulit yang membesar, sehingga merupakan hal yang penting untuk merawat kulit itu sendiri (Grace, 20I5).

Radikal bebas menjadi penyebab masalah kulit. Radikal bebas merupakan molekul yang dapat berdiri sendiri mengandung satu atau lebih elektron yang tidak berpasangan (Yuslianti, 2018). Radikal bebas pada kulit yang diproduksi berlebih dapat merusak kolagen pada membran sel kulit, sehingga kulit kehilangan elastisitasnya dan menyebabkan terjadinya keriput.

Senyawa yang dapat menangkal radikal bebas adalah antioksidan. Penggunaan antioksidan efektif untuk mencegah kerusakan kulit akibat proses penuaan. Penggunaannya dapat dilakukan secara oral maupun topikal. Antioksidan mampu menekan radikal bebas dan mampu mengurangi terjadinya reaksi oksidasi. Salah satu antioksidan yang terdapat dialam adalah buah Tampoi.

Buah Tampoi (Baccaurea macrocarpa) merupakan salah satu anggota dari family Phyllanthaceae. Pemanfaatan buah Tampoi (Baccaurea macrocarpa) oleh suku Dayak Kalimantan masih terbatas pada komsumsi buah dan bahan untuk pembuatan minuman tuak. Penelitian yang telah dilakukan terhadap daging buah Tampoi menunjukkan aktivitas antioksidan dengan nilai $\mathrm{EC}_{50} 33, \mathrm{Il} \mu \mathrm{g} / \mathrm{ml}$ (Endra Tirtanal*, Nora Idiawatil, Warsidahl 20l3). Hal ini sejalan dengan penelitian uji antioksidan yang menyatakan bahwa hasil uji DPPH, ABTS dan FRAP pada Baccaurea macrocarpa menampilkan kapasitas antioksidan tertinggi. Aktivitas antioksidan dari ekstrak secara signifikan berkorelasi dengan kandungan total fenolik dan flavonoid, tetapi tidak dengan kandungan karotenoid. Kandungan flavonoid memiliki aktivitas yang bermanfaat selain antioksidan juga sebagai antibakteri (Noval, Yuwindry, and Syahrina 2019). Antioksidan dalam tubuh manusia sangat diperlukan hal ini untuk mencegah atau menunda oksidasi ketika terkena radikal bebas (Cahyani, Dwi, and Putri 2017).

Berdasarkan dari permasalahan yang terjadi maka diperlukan sebuah inovasi dari kearifan lokal. Dengan pengembangan inovasi kearifan lokal sebuah produk masker perawatan kulit dari ekstrak buah tampoi (Noval, Nastiti, Nugraha, Rahmadani, Alawiyah 2020). Masker merupakan sediaan kosmetik untuk perawatan kulit yang memiliki banyak manfaat seperti memberikan kelembaban, memperbaiki tekstur kulit, meremajakan, mengencangkan, melembutkan, membersihkan poripori, mencerahkan warna kulit, merelaksasikan otototot wajah, menghilangkan jerawat dan bekas jerawat. Efek yang dirasakan dari perawatan menggunakan masker yang mengandung antioksidan adalah revitalisasi, penyembuhan, penyegaran yang dapat memberikan manfaat sementara dan jangka panjang.

Dari latar belakang diatas maka tujuan penelitian ini adalah untuk memanfaatkan kearifan lokal melalui buah eksotis khas Kalimantan buah tampoi (Baccaurea macrocarpa) dengan menformulasikan buah tampoi menjadi sediaan masker gel sebagai antioksidan. Urgensi penelitian buah tampoi dikarenakan asli khas Kalimantan yang belum banyak diteliti manfaatnya karena buah tampoi masih sangat terbatas dan hanya tersedia di kalangan masyarakat lokal Kalimantan. Oleh karena itu penelitian ini penting dilakukan untuk menggali lebih jauh pemanfaatannya selain sebagai konsumsi juga sebagai perawatan tubuh berupa masker perawatan kulit untuk mencegah terjadinya penuaan dini, selain itu juga dengan diketahuinya buah tampoi memiliki banyak manfaat, tanaman ini bisa dibudidayakan, dilestarikan dan dikembangkan menjadi suatu produk. 


\section{METODOLOGI}

\section{Alat dan Bahan}

Alat yang digunakan dalam penelitian ini meliputi rotary evaporator, timbangan analitik, gelas beker, botol maserasi, erlenmeyer, corong, indikator $\mathrm{pH}$ universal, viskometer, hot plate, kemasan masker gel, stamper, mortir, alat uji daya sebar.

Bahan yang digunakan pada penelitian ini buah tampoi, etanol 70\%, Carbopol, PVA, propilenglikol, metilparaben, aquadest, peppermint oil, alumunium foil, kertas saring, kapas, label, tissue.

\section{Metode Penelitian}

Sampel buah tampoi (Baccaurea macrocarpa) didapatkan dari Kabupaten Tabalong, Kalimantan Selatan.

\section{Pembuatan Ekstrak Buah Tampoi.}

Ekstraksi menggunakan metode maserasi. Tahapan ekstraksi adalah sebagai berikut:

I. Simplisia dari buah tampoi (Baccaurea macrocarpa)

2. Dimasukkan etanol ke dalam bejana sampai merendam simplisia setinggi $2-3 \mathrm{~cm}$

3. Bejana maserasi ditutup dan dibiarkan rendaman selama 3 hari sambil sesekali di aduk

4. Cairan hasil ekstraksi dikeluarkan dari bejana dengan disaring

5. Filtrat kemudian diuapkan menggunakan rotary evaporator sampai didapatkan ekstrak kental.

6. Ekstrak kental yang didapat kemudian dimasukkan dalam formulasi masker gel

Formulasi sediaan masker gel adalah sebagai berikut

Tabel I. Variasi Formulasi Masker Gel

\begin{tabular}{|c|c|c|c|c|}
\hline Komposisi & $\begin{array}{l}\mathrm{FI} \\
(\mathrm{g})\end{array}$ & FII (g) & FIII (g) & FIII $(g)$ \\
\hline $\begin{array}{l}\text { Ekstrak Metanol Buah } \\
\text { tampoi }\end{array}$ & 0,30 & 0,30 & 0,30 & 0,30 \\
\hline PVA & 3 & 6 & 12 & 18 \\
\hline Propylene gliko & 6 & 6 & 6 & 6 \\
\hline Carborner 940 (carbopol) & 2 & 2 & 2 & 2 \\
\hline Essense Paper mint oil & 0,01 & 0,01 & 0,01 & 0,01 \\
\hline
\end{tabular}

\begin{tabular}{lcccc}
\hline Metil Paraben & 0,18 & 0,18 & 0,18 & 0,18 \\
\hline Water ad & 100 & 100 & 100 & 100 \\
\hline
\end{tabular}

PVA dikembangkan ke dalam air panas selama 15 menit kemudian digerus sampai membentuk warna dan transparan. Carbopol pada tempat yang berbeda dikembangkan pada air panas hingga homogen dan jernih. Tambahkan metil paraben yang telah dilarutkan dalam propylene glikol. Dicukupkan dengan aquades sedikit demi sedikit dan digerus sampai homogen dan diperoleh dasar gel. Tambahkan ekstrak ke dalam basis gel dan digerus hingga homogen.

Evaluasi sediaan masker gel buah tampoi

I. Uji organoleptis

Pemeriksaan terhadap organoletik yang dilakukan meliputi tekstur, wara dan bau yang diaati secara visual (Kurniawati, Noval, and Nastiti 2020).

2. $\mathrm{Uji} \mathrm{pH}$

Pengujian ph menggunakan kertas $\mathrm{PH}$ Universal (Noval, Melviani, Novia, Syahrina 2020).

3. Uji viskositas

Pengujian viskostas menggunakan viskometer stormer dengan kecepatan 12, 30 dan 60 rpm (Noval, Rosyifa, and Annisa 2020a).

4. Uji daya sebar

Ditimbang 500 mg gel dan diletakan di tengah kaca bulat berskala, sebelumnya ditimbang dahulu kaca yang lain dan diletakan kaca tersebut di atas gel dan dibiarkan selama I menit. Kemudian diukur beberapa diameter gel yang menyebar dengan mengambil panjang rata-rata diameter dari beberapa sisi. Kemudian ditambahkan 50,0 mg beban tambahan dan didiamkan selama I menit. Dicatat diameter gel yang menyebar dan diteruskan dengan menambah tiap kali beban tambahan 50,0 mg (Noval, Rosyifa, and Annisa 2020a).

5. Uji daya lekat 
Pengujian daya lekat dilakukan dengan cara menimbang 0,5 gram hidrogel yang diletakkan pada salah satu permukaan kaca objek kemudian ditutup dengan kaca objek yang lain. Kaca objek ditindih dengan beban I kg selama 5 menit. Kaca objek yang berhimpit kemudian dipasang pada alat uji daya lekat dan bersamaan dengan pemberian beban 80 gram pada alat uji daya lekat, catat waktu ketika lekatan terlepas dengan menurunkan beban 80 gram (Sari, Nurbaeti, and Pratiwi 2016).

\section{HASIL DAN PEMBAHASAN}

Masker gel adalah sediaan kosmetik untuk perawatan kulit wajah dimana berfungsi untuk menjaga kesehatan kulit dan merupakan salah satau produk yang banyak diminati oleh sebagian masyarakat dan banyak beredar di pasaran. Sediaan masker gel buah tampoi (Baccaurea macrocarpa) merupakan salah satu masker yang berfungsi sebagai antiaging. Hasil pengamatan dari penelitian yang telah dilakukan terhadap sediaan masker gel dari ekstrak buah Tampoi (Baccaurea macrocarpa) yang meliputi pengamatan organoleptis (warna, bentuk, dan bau), pemeriksaan $\mathrm{pH}$, penentuan vikositas, uji daya sebar, dan uji daya lekat. Adapun hasil evaluasi uji organoleptis dapat dilihat pada tabel di bawah ini:

\section{Uji Organoleptis}

Tabel II. Hasil Uji Organoleptis Formulasi Buah Tampoi

(Baccaurea macrocarpa) dalam Sediaan Masker Gel

\begin{tabular}{cccccc}
\hline Organoleptis & Minggu & \multicolumn{3}{c}{ Formula } \\
\cline { 3 - 6 } & ke- & F1 & F2 & F3 & F4 \\
\hline Tekstur & 1 & $\begin{array}{c}\text { Agak } \\
\text { kental }\end{array}$ & Kental & Kental & Kental \\
& 2 & $\begin{array}{c}\text { Agak } \\
\text { kental }\end{array}$ & Kental & Kental & Kental \\
& & Agak & Kental & Kental & Kental \\
& & & & & \\
& 4 & Agak & Kental & Kental & Kental \\
& & kental & & & \\
\hline Warna & 1 & Putih & Putih & Putih & Putih \\
& 2 & Putih & Putih & Putih & Putih \\
& 3 & Putih & Putih & Putih & Putih
\end{tabular}

\begin{tabular}{cccccc} 
& 4 & Putih & Putih & Putih & Putih \\
\hline Bau & 1 & Bau & Bau & Bau & Bau \\
& & ekstrak & ekstrak & ekstrak & ekstrak \\
& 2 & Bau & Bau & Bau & Bau \\
& & ekstrak & ekstrak & ekstrak & ekstrak \\
& 3 & Bau & Bau & Bau & Bau \\
& & ekstrak & ekstrak & ekstrak & ekstrak \\
& 4 & Bau & Bau & Bau & Bau \\
& & ekstrak & ekstrak & ekstrak & ekstrak \\
\hline
\end{tabular}

Uji organoleptis dilakukan dengan melihat tekstur, warna dan bau yang dirasakan oleh indra peraba (Zhelsiana, et al., 2016)). Uji organoleptis bertujuan untuk mendapatkan sediaan masker gel yang memiliki tekstur yang nyaman, warna dan bau yang menarik dan dapat diterima oleh pengguna. Berdasarkan hasil uji organoleptis, perbandingan I, 2, 3, dan 4 serta formulasi FI, F2, F3, F4. Data evaluasi tekstur menunjukan bahwa sediaan tidak mengalami perubahan selama 4 minggu penyimpanan. Pada formulasi FI memiliki tekstur agak kental, dan formulasi F2, F3, dan F4 memiliki tekstur kental. Adapun hasil evaluasi warna adalah warna putih dan tidak mengalami perubahan selama 4 minggu penyimpanan, begitupula dengan evaluasi bau yaitu bau khas ekstrak peppermint. Bau pada sediaan dipengaruhi oleh penggunaan peppermint oil.

Dari hasil tersebut menunjukan bahwa semakin tinggi konsentrasi formulasi, semakin pekat sediaan yang dihasilkan.

2. Uji Ph

Tabel III. Hasil Uji pH Formulasi Buah Tampoi

(Baccaurea macrocarpa) dalam Sediaan Masker Gel

\begin{tabular}{ccccc}
\hline \multirow{2}{*}{ Formula } & \multicolumn{4}{c}{$\mathrm{pH}$} \\
\cline { 2 - 5 } & $\begin{array}{c}\text { Minggu } \\
\text { ke-I }\end{array}$ & $\begin{array}{c}\text { Minggu } \\
\text { ke-2 }\end{array}$ & $\begin{array}{c}\text { Minggu } \\
\text { ke-3 }\end{array}$ & $\begin{array}{c}\text { Minggu } \\
\text { ke-4 }\end{array}$ \\
\hline FI & 3,95 & 3,20 & 3,34 & 3,96 \\
F2 & 3,98 & 3,40 & 3,49 & 3,43 \\
F3 & 4,12 & 3,75 & 3,80 & 3,55 \\
F4 & 4,27 & 3,95 & 3,96 & 3,87 \\
\hline
\end{tabular}

Pengujian $\mathrm{pH}$ dilakukan untuk mengetahui apakah formulasi yang dibuat bersifat asam, basa atau netral, hal ini dilakukan untuk mengetahui kesesuaian dan keamanan sediaan terhadap kulit agar tidak terjadi 
iritasi. Pada tabel II dapat dilihat bahwa hasil pengujian $\mathrm{pH}$ dengan penambahan ekstrak buah tampoi berpengaruh pada penurunan $\mathrm{pH}$, ini disebabkan oleh karena adanya kandungan senyawa dari ekstrak buah tampoi yang bersifat asam sehingga dapat menurunkan $\mathrm{pH}$ pada masker. Pada penyimpanan pada minggu ke-I hingga minggu ke-4 formula terjadi penurunan $\mathrm{pH}$ pada tiap penyimpanan. Akan tetapi penurunan yang terjadi tidak signifikan dan relatif stabil pada penyimpanan.

Hasil pemeriksaan uji $\mathrm{pH}$ tiap formula pada minggu keI hingga minggu ke-4 menunjukan $\mathrm{pH}$ formula rata-rata berkisar antara 3,20-4,27. Hasil pemeriksaan uji pH dapat dikatakan belum memenuhi kriteria $\mathrm{pH}$ kulit normal, karena kategori $\mathrm{pH}$ kulit normal berkisar 4,56,5 (Taurina, et l., 2018). Sehingga pada penelitian ini perlu penambahan zat yang bersifat basa untuk meningkatkan $\mathrm{pH}$ sehingga dapat diterima oleh kulit dan tidak menyebabkan iritasi ketika diaplikasikan. $U_{j i} \mathrm{pH}$ penting untuk mengetahui tingkat keasaman dari formulasi yang dibuat agar formulasi tidak mengiritasi kulit dan tidak menyebabkan kulit kering (Desiyana, et al., 2016) (Noval, Rosyifa, and Annisa 2020a).

Hasil analisis perbedaan $\mathrm{pH}$ pada masing-masing formula menggunakan uji Anova menunjukkan tidak ada perbedaan yang signifikan dengan nilai p-value 0, 165 .

3. Uji Vikositas

Tabel IV. Hasil Uji Vikositas Formulasi Buah Tampoi

(Baccaurea macrocarpa) dalam Sediaan Masker Gel

\begin{tabular}{cccccc}
\hline & & \multicolumn{4}{c}{ Visikositas (mPa.S) } \\
\cline { 3 - 6 } Formula & Ppm & $\begin{array}{c}\text { Minggu } \\
\text { ke-I }\end{array}$ & $\begin{array}{c}\text { Minggu } \\
\text { ke-2 }\end{array}$ & $\begin{array}{c}\text { Minggu } \\
\text { ke-3 }\end{array}$ & $\begin{array}{c}\text { Minggu } \\
\text { ke-4 }\end{array}$ \\
\hline FI & 12 & 5566 & 10233 & 3166 & 7783 \\
& 30 & 2339 & 4820 & 1490 & 4820 \\
& 60 & 2153 & 1995 & 1323 & 2853 \\
\hline F2 & 12 & 27816 & 11598 & 13866 & 35833 \\
& 30 & 13226 & 6900 & 6353 & 15220 \\
& 60 & 7530 & 4473 & 4043 & 9366 \\
\hline F3 & 12 & 42750 & 37720 & 39240 & 41135 \\
& 30 & 31720 & 28250 & 24360 & 30220 \\
& 60 & 14070 & 11620 & 11330 & 17450 \\
\hline F4 & 12 & 65020 & 51330 & 49720 & 69250 \\
& 30 & 41420 & 29370 & 27540 & 28130
\end{tabular}

$\begin{array}{lllll}60 & 25340 & 22420 & 19250 & 15550\end{array}$

Viskositas dari suatu sediaan merupakan salah satu parameter yang penting untuk mengetahui apakah gel yang dibuat telah optimal. Gel yang memiliki viskositas sangat rendah dapat menyebabkan waktu kontak sediaan dengan kulit tidak optimal sehingga akan mempengaruhi aktivitas zat aktif yang terkandung, sedangkan viskositas yang terlalu besar akan meningkatkan waktu retensi dan juga menurunkan daya sebar dari sediaan. Nilai viskositas yang baik untuk sediaan topikal adalah 6000-24000 cps, serta nilai viskositas sediaan gel yang baik antara 2000-4000 cP (Andini, Yusriadi, and Yuliet 2017) (Noval, Rosyifa, and Annisa 2020a). Berdasarkan hasil uji vikositas dapat dilihat pada tabel III. Menunjukkan bahwa seluruh formula telah memenuhi persyaratan viskositas gel yang baik dengan nilai viskositas tersebar ditunjukkan oleh F4 dibanding formula lainnya. Tingginya nilai viskositas pada F4 karena formulasi ini memiliki kandungan PVA dengan konsentrasi terbesar dibanding formula lainnya, nilai PVA berbanding lurus dengan nilai viskositas sehingga semakin tinggi konsentrasi PVA yang ditambahkan maka semakin tinggi nilai viskositas yang diperoleh. Peningkatan konsentrasi PVA yang ditambahkan dapat meningkatkan jumlah serat serta polimer di dalam sediaan sehingga akan menyebabkan semakin banyak cairan yang tertahan dan terikat oleh agen pembentuk gel yang menyebabkan nilai viskositas sediaan semakin meningkat (Aprilianti, Hajrah, and Sastyarina 2020). Hasil pengujian stabilitas viskositas gel selama 4 minggu menunjukkan terjadinya peningkatan nilai viskositas pada seluruh formula setelah penyimpanan.

Sifat alir gel menunjukkan pada semua formua gel memiliki sifat alir pesudoplastis karena menunjukkan penurunan nilai viskositas yang didapat ketika semakin meningkatnya kecepatan putaran yang diberikan. Setelah dilakukan pengujian kembali setelah 
penyimpanan selama 4 minggu menunjukkan semua formula gel tetap mempunyai sifat alir pseudoplastis dengan nilai viskositas yang semakin meningkat pada tiap minggu pengukuran. Hal ini karena gaya gesek diberikan maka rantai-rantai polimer yang ada dalam sediaan tergulung secara acak dan akan terlepas menjadi bentuk yang lebih panjang dan lurus sehingga menyebabkan viskositas akan menurun. Akan tetapi aktivitas dari polimer-polimer ini akan kembali kebentuk awal ketika disimpan dan menyebabkan viskositas kembali meningkat (Noviani, Noor, and Nengsih 2016).

Hasil analisis menggunakan uji Anova didapatkan hasil pada masing-masing formula pada rpm 30 dan 60 menunjukkan adanya perbedaan yang signifikan dengan nilai $\mathrm{p}$-value masing-masing adalah $0,000 \mathrm{I}$.

4. Uji Daya Sebar

Tabel V. Hasil Uji Daya Sebar Formulasi Buah Tampoi (Baccaurea macrocarpa) dalam Sediaan Masker Gel

\begin{tabular}{|c|c|c|c|c|c|}
\hline & \multirow{2}{*}{$\begin{array}{c}\text { Minggu } \\
\text { ke- }\end{array}$} & \multicolumn{4}{|c|}{ Formula } \\
\hline \multirow{9}{*}{$\begin{array}{c}\text { Uji Daya } \\
\text { Sebar }\end{array}$} & & $\mathrm{FI}$ & F2 & F3 & F4 \\
\hline & \multirow[b]{2}{*}{ I } & 4,10 & 4,55 & 3,15 & 3,32 \\
\hline & & $\mathrm{cm}$ & $\mathrm{cm}$ & $\mathrm{cm}$ & $\mathrm{cm}$ \\
\hline & \multirow[b]{2}{*}{2} & 4,15 & 3.6 & 3,05 & 2,5 \\
\hline & & $\mathrm{cm}$ & $\mathrm{cm}$ & $\mathrm{cm}$ & $\mathrm{cm}$ \\
\hline & \multirow{2}{*}{3} & 4,225 & 2,8 & 2,45 & $2 \mathrm{~cm}$ \\
\hline & & $\mathrm{cm}$ & $\mathrm{cm}$ & $\mathrm{cm}$ & \\
\hline & \multirow{2}{*}{4} & 3,125 & 2,125 & $2 \mathrm{~cm}$ & $2 \mathrm{~cm}$ \\
\hline & & $\mathrm{cm}$ & $\mathrm{cm}$ & & \\
\hline
\end{tabular}

Pengujian daya sebar bertujuan untuk menunjukkan kemampuan suatu sediaan untuk menyebar ketika dioleskan di kulit tanpa adanya tekanan yang berlebihan ketika dioleskan (Cahyani, Dwi, and Putri 2017). Hasil uji daya sebar gel ekstrak tanaman bundung dapat dilihat pada tabel IV. Yang menunjukkan adanya pengaruh basis gel dimasing-masing formula terhadap daya sebar gel. Daya sebar sediaan gel yang baik adalah $5-7 \mathrm{~cm}$ atau 5,54-6,08 cm berdasarkan SNI, sedangkan daya sebar sediaan semipadat yang baik untuk penggunaan topikal berkisar pada diameter 3-5 cm (Noval, Rosyifa, and Annisa 2020a). Hasil daya sebar yang diperoleh menunjukkan kisaran nilai 3-4 cm yang menunjukkan bahwa hasil ini telah memenuhi daya sebar sediaan semipadat yang baik. F3 dan F4 menunjukkan nilai daya sebar yang lebih kecil dibanding FI dan F2, hal ini dikarenakan memiliki kandungan konsentrasi PVA yang lebih tinggi pada kedua formulasi tersebut sehingga akan memepengaruhi kekentalan gel yang dibuat dan nilai daya sebar akan semakin kecil. Semakin tinggi konsentrasi PVA yang ditambahkan maka daya sebar dari suatu sediaan akan semakin menurun (Sinala, Afriani, and Arisanty 2019).

Pengukuran daya sebar dilakukan dari minggu ke-I sampai dengan minggu ke-4. Hasil pengukuran selama penyimpanan menunjukkan penurunan nilai daya sebar gel dengan FI yang menunjukkan nilai daya sebar masih masuk ke dalam rentang daya sebar sediaan semipadat. Sedangkan untuk F2, F3, dan F4 menunjukkan penurunan nilai yang tidak sesuai dengan daya sebar sediaan semipadat. Penurunan daya sebar ini dapat disebabkan karena meningkatnya ukuran molekul dari PVA karena mengabsorbsi pelarut yang terkandung selama penyimpanan sehingga akan meningkatkan tahanan untuk mengalir dan menyebar (Aprilianti, Hajrah, and Sastyarina 2020).

Hasil analisis uji daya sebar menggunakan uji Anova didapatkan hasil pada masing-masing formula menunjukkan tidak adanya perbedaan yang signifikan dengan nilai $p$-value 0,057 .

\section{Uji Daya Lekat}

Table VI. Hasil Uji Daya Lekat Formulasi Buah Tampoi

(Baccaurea macrocarpa) dalam Sediaan Masker Gel

\begin{tabular}{|c|c|c|c|c|c|}
\hline \multirow{5}{*}{$\begin{array}{c}\text { Uji Daya } \\
\text { Lekat }\end{array}$} & \multirow{2}{*}{$\begin{array}{c}\text { Minggu } \\
\text { ke- }\end{array}$} & \multicolumn{4}{|c|}{ Formula } \\
\hline & & $\mathrm{FI}$ & $\mathrm{F} 2$ & F3 & F4 \\
\hline & I & $\begin{array}{c}\text { II } \\
\text { detik }\end{array}$ & 7 detik & $\begin{array}{l}\mathrm{I}, 54 \\
\text { detik }\end{array}$ & $\begin{array}{l}24,34 \\
\text { detik }\end{array}$ \\
\hline & 2 & 6 detik & $\begin{array}{c}\text { I I } \\
\text { detik }\end{array}$ & $\begin{array}{c}4,04 \\
\text { menit }\end{array}$ & $\begin{array}{c}5,42 \\
\text { menit }\end{array}$ \\
\hline & 3 & $\begin{array}{l}2,15 \\
\text { detik }\end{array}$ & $\begin{array}{l}\text { I5,04 } \\
\text { detik }\end{array}$ & $\begin{array}{c}2 \\
\text { menit }\end{array}$ & $\begin{array}{c}4 \text { menit } 2 \\
\text { detik }\end{array}$ \\
\hline
\end{tabular}




\begin{tabular}{lllll}
\hline 4 & 7,15 & 9,59 & 13,50 & 2 menit \\
& detik & detik & detik & 54 detik \\
\hline
\end{tabular}

Pengujian daya lekat akan menunjukkan kemampuan sediaan gel untuk dapat melekat atau menempel pada kulit ketika digunakan sehingga dapat memberikan efek yang maksimal. Sediaan gel yang baik memiliki nilai daya lekat tidak kurang dari 4 detik (Amaliah, Rahmawanty, and Ratnapuri 2018). Berdasarkan tabel V. hasil pengujian daya lekat menunjukkan FI, F2 dan F4 pada minggu pertama pengujian telah memenuhi persyaratan daya lekat masker gel yang baik sedangkan F3 belum memenuhi nilai daya lekat yang baik. Nilai daya lekat terbesar ditunjukkan oleh F4, hal ini karena F4 memiliki kandungan PVA dengan konsentrasi paling besar dibanding formula lainnya. Penambahan PVA yang semakin besar akan menyebabkan nilai daya lekat semakin meningkat karena bobot molekul yang terkandung di dalamnya akan semakin tinggi dan meningkatkan kemampuannya untuk melekat dari sediaan yang dibuat (Arinjani and Ariani 2009).

Pengujian setelah penyimpanan selama 4 minggu menunjukkan hasil nilai daya lekat mengalami peningkatan dan penurunan pada tiap formula dan menunjukkan nilai yang masih termasuk ke dalam rentang persyaratan nilai daya lekat sediaan masker gel kecuali pada FI terdapat nilai daya sebar yang tidak sesuai pada minggu ke-3 pengujian. Hal ini dapat disebabkan karena pada penyimpanan polimer di dalam sediaan gel akan menyerap pelarut dan kelembapan selama penyimpanan sehingga akan mempengaruhi hasil nilai daya lekat.

Hasil analisis uji daya lekat menggunakan uji Anova didapatkan hasil pada masing-masing formula menunjukkan adanya perbedaan yang signifikan dengan nilai $\mathrm{p}$-value 0,046 .

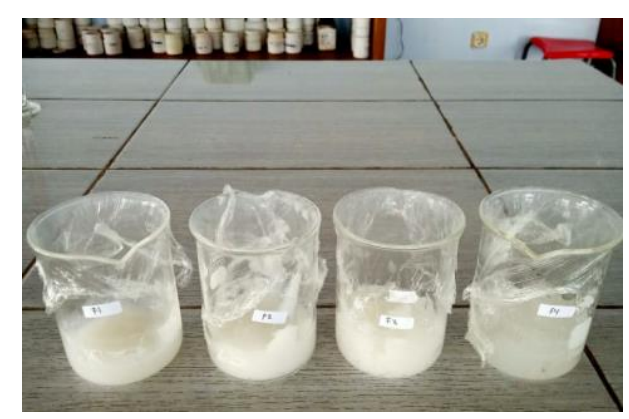

Gambar I. Sediaan Masker Gel Buah Tampoi (Baccaurea macrocarpa)

\section{KESIMPULAN}

Berdasarkan penelitian yang telah dilakukan dalam formulasi sediaan masker gel buah tampoi didapatkan hasil evaluasi yang dilakukan dalam penyimpanan 4 minggu bahwa 4 formulasi dengan variasi konsentrasi PVA memiliki pengaruh terhadap uji viskositas, uji daya sebar dan uji daya lekat. Penyimpanan selama 4 minggu menunjukkan adanya pengaruh dari semua uji yang tidak signifikan sehingga tetap berada dalam rentang yang dipersyaratkan. Formulasi yang optimal berada pada FI dengan konsentrasi PVA $3 g$. Berdasarkan analisis uji Anova didapatkan hasil bahwa pada uji pH dan uji daya sebar tidak ada perbedaan yang signifikan pada masing-masing formula. Sedangkan pada uji viskositas dan uji daya lekat menunjukkan adanya perbedaan yang signifikan.

\section{UCAPAN TERIMA KASIH}

Peneliti mengucapkan terimakasih yang sebesarbesarnya kepada Kementrian Riset dan Teknonologi atau Badan Riset dan Inovasi Nasional Republik Indonesia yang mendanai penelitian ini melalui skema hibah Penelitian Dosen Pemula di tahun 2020. 


\section{REFERENSI}

I. Grace, F.X., C. Darsika, K. V. Sowmya, K. Sungaya, and S. Shanmuganathan. 20I5. Preparation and Evaluation of Herbal Peel Off Face Mask. American

2. Yuslianti, Euis Reni. 2018. Pengantar Radikal Bebas dan Antioksidan. Ed.I, Cet. I-Yogyakarta: Deepublish.

3. Endra Tirtanal*, Nora Idiawatil, WarsidahI, Afghani Jayuskal. 2013. "Issn 2303-1077 Analisa Proksimat, Uji Fitokimia Dan Aktivitas Antioksidan Pada.” Jurnal Kajian Komunikasi 2(I): 42-45.

4. Noval, Noval, Iwan Yuwindry, and Dahlia Syahrina. 2019. "Phytochemical Screening and Antimicrobial Activity of Bundung Plants Extract by Dilution Method.” Jurnal Surya Medika.

5. Cahyani, Intan Martha, Indah Dwi, and Cahyo Putri. 2017. "Formulation of Peel-Off Gel From Extract Of Curcuma Heyneana Val \& Zijp Using Carbopol 940 Efektivitas Karbopol 940 Dalam Formula Masker Gel Peel-Off Ekstrak Temu Giring ( Curcuma Heyneana Val \& Zijp )." Journal of Pharmaceutical and Medicinal Sciences 2(2): 48-5I.

6. Noval, N., Nastiti, K., Nugraha, D., Rahmadani, R., \& Alawiyah, T. (2020). PRODUK INOVASI HAND SANITIZER DARI AKAR BAJAKAH SEBAGAI UPAYA PENCEGAHAN DI MASA PANDEMI COVID-19. LOGISTA - Jurnal Ilmiah Pengabdian Kepada Masyarakat, 4(2), 305-312. doi: | 0.25077/logista.4.2.305-3 | 2.2020

7. Kurniawati, Darini, Noval Noval, and Kunti Nastiti. 2020. "POTENSI ANTISEPTIK POLIHERBAL DAUN SIRIH (Piper Betle), KULIT JERUK NIPIS (Citrus Aurantifolia) DAN TANAMAN BUNDUNG (Actinuscirpus Grossus) PADA TINDAKAN KEPERAWATAN DAN KEBIDANAN." Dinamika Kesehatan: Jurnal Kebidanan Dan Keperawatan I I(I): 420-3I.

8. Noval, Noval, Melviani Melviani, Novia Novia, and Dahlia Syahrina. 2020. "Formulasi Dan Evaluasi Sediaan Obat Kumur (Mouthwash) Dari Ekstrak Etanol Tanaman Bundung (Actinoscirpus Grossus)
Sebagai Antiseptik Mulut". Jurnal Surya Medika (JSM) $6 \quad$ (I), II2-20. https://doi.org/l0.33084/jsm.v6il.1626.

9. Noval, Noval, Rosyifa Rosyifa, and Annisa Annisa. 2020a. "Effect of HPMC Concentration Variation as Gelling Agent on Physical Stability of Formulation Gel Ethanol Extract Bundung Plants (Actinuscirpus Grossus)."

10. Noval, Rosyifa, and Annisa. 2020b. "Effect of HPMC Concentration Variation as Gelling Agent on Physical Stability of Formulation Gel Ethanol Extract Bundung Plants (Actinuscirpus Grossus)."

II. Zhelsiana, D. A., Pangestuti, Y. S., Nabilla, F., Lestari, N. P., \& Wikantyasning, E. R. (20/6). Formulasi Dan Evaluasi Sifat Fisik Masker Gel PeelOff Lempung Bentonite. The 4 Th Univesity Research Coloquium, 42-45.

12. Taurina, Wintari, Mohamad Andrie, and Lea Anjeli. 2018. "The Gel Formulation of the Aqueous Phase of Snakehead Fish ( Channa Striata ) Extract with Various Combinations of HPMC K4M and Carbopol 934." Pharmaciana 8(I): 97-106.

13. Desiyana, Lydia Septa, Muhammad Ali Husni, and Seila Zhafira. 2016. "Uji Efektivitas Sediaan Gel Fraksi Etil Asetat Daun Jambu Biji ( Psidium Guajava Linn ) Terhadap Penyembuhan Luka Terbuka Pada Mencit (Mus Musculus )*.” Jurnal Natural I6(2): I I12

14. Andini, Tricia, Yusriadi Yusriadi, and Yuliet Yuliet. 2017. "Optimasi Pembentuk Film Polivinil Alkohol Dan Humektan Propilen Glikol Pada Formula Masker Gel Peel off Sari Buah Labu Kuning (Cucurbita Moschata Duchesne) Sebagai Antioksidan." Jurnal Farmasi Galenika (Galenika Journal of Pharmacy) (e-Journal) 3(2): 165-73.

15. Aprilianti, Nur, Hajrah, and Yurika Sastyarina. 2020. "Optimasi Polivinilalkohol (PVA) Sebagai Basis Sediaan Gel Antijerawat." Proceeding of Mulawarman Pharmaceuticals Conferences: 26-27.

16. Noviani, Yuslia, Siti Umrah Noor, and Erni Nengsih. 
2016. "Pengaruh Variasi Konsentrasi Polivinil Alkohol ( PVA ) Pada Formulasi Masker Gel PeelOff Ekstrak Belimbing Wuluh ( Averrhoa Bilimbi L .) Sebagai Anti Jerawat ( The Effect of Various Concentrations of Polyvinyl Alcohol ( PVA ) in Peel-off Gel Mask Formula.” Jurnal Ilmu Kefarmasian Indonesia 14(2): 199-205.

17. Sinala, Santi, Amalia Afriani, and Arisanty. 2019. "Formulasi Sediaan Masker Gel Peel Off Dari Sari Buah Dengen (Dillenia Serrata)." Media Farmasi XV(2): I78-84.

18. Amaliah, Rizky Nur, Dina Rahmawanty, and Prima Happy Ratnapuri. 2018. "Pengaruh Variasi Konsentrasi PVA Dan HPMC Terhadap Stabilitas Fisik Masker Gel Peel-Off Ekstrak Metanol Biji Pepaya ( Carica Papaya L .).” Jurnal Pharmascience 05(0I): 78-85.

19. Arinjani, Siti, and Lilies Wahyu Ariani. 2009. "Pengaruh Variasi Konsentrasi PVA Pada Karakteristik Fisik Sediaan Masker Gel Peel Off Ekstrak Daun Ungu (Graptophyllum Pictum L. Griff).” Media Farmasi Indonesia V(2): I525-30.

20. Sari, Rafika, Siti Nani Nurbaeti, and Liza Pratiwi. 2016. "Optimasi Kombinasi Karbopol 940 Dan HPMC Terhadap Sifat Fisik Gel Ekstrak Dan Fraksi Metanol Daun Kesum (Polygonum Minus Huds.) Dengan Metode Simplex Lattice Design." Pharmaceutical Sciences and Research 3(2): 72-79.

21. Journal of PharmTech Research. (5): 33336. 